\title{
Husbands' Involvement in Female Gender-Typed Household Chores ${ }^{1}$
}

\author{
Marjorie E. Starrels ${ }^{2}$ \\ University of Michigan
}

Using data from the National Survey of Children (sample is $89 \%$ White, $9 \%$ Black, 2\% Hispanic or other), this paper examines levels and correlates of husbands' involvement in traditionally female household chores. Analyses reveal that the vast majority of wives assume primary responsibility for these daily and non-daily tasks. Only about one-fifth of husbands are involved fully in these activities. OLS and logistic regression models show that structural and ideational variables with respect to women are the strongest predictors of men's involvement. Resource, time availability, socialization, and life course models of husbands' household labor all garner significant support, and family process is a significant factor as well. This study demonstrates important interactive effects between predictors, thus suggesting the need for synthesizing various theoretical perspectives on the household division of labor.

For the past two decades, we have witnessed dramatic shifts in gender roles within the family and the workplace. Due to increasing rates of women's labor force participation, the traditional, single earner family has become the exception rather than the norm. Simultaneously, a new cultural ideal of role-sharing in housework and child care has arisen in the U.S. (Antill \& Cotton, 1988; Coltrane, 1989; Kamo, 1988; Pahl, 1989). However, research consistently finds that couples who express egalitarian attitudes do not necessarily translate their values into behavior (Condran and Bode, 1982; Bryson, Bryson, Licht \& Licht, 1976; Hiller \& Philliber, 1986; Hochschild, 1989).

\footnotetext{
${ }^{1}$ An earlier version of this paper was presented at the American Sociological Assocation Annual Meeting, August 23-27, 1991, Cincinnati. The author gratefully acknowledges Sampson Blair and Beth Anne Shelton for helpful comments and Marc Hallee for research assistance.

${ }^{2}$ To whom correspondence should be addressed at School of Social Work, 1065 Frieze Bldg., University of Michigan, Ann Arbor, MI 48109-1285.
} 
Even in dual-earner couples in which spouses spend comparable hours in paid labor, women do the vast majority of housework. In fact, dual-career wives spend nearly three times as many hours per week doing housework as their husbands (Berardo, Shehan, \& Leslie, 1987). Moreover, these women continue to perform most of the traditionally female tasks, which typically require daily attention. With women's work week roughly 15 hours longer than men's, women are clearly taking on a second shift of work in the home (Hochschild, 1989).

Egalitarian attitudes are important predictors of men's involvement in housework. Wives with more liberal attitudes are more likely to have role-sharing husbands (Barnett \& Baruch, 1987). Studies consistently find that the more husbands and wives hold similar egalitarian views of marriage, the more household tasks are shared, albeit unevenly (Antill \& Cotton, 1988; Hardesty \& Bokemeier, 1989; Coltrane, 1989; Ross, 1987). Note, however, that couples in which both spouses have egalitarian beliefs are not the norm. Men are much more likely than women to espouse traditional values (Hochschild, 1989).

Notwithstanding frequent congruence between division of labor and gender ideology, studies also identify a common pattern in which attitudes and behavior diverge. Therefore, attitudes may be viewed as merely one factor in determining labor allocation. Indeed, structural and ideational forces may interact in complex and subtle ways. For instance, when a wife works full-time or has a high income, even from a part-time job, and has a relatively liberal gender-role orientation, her husband participates more fully in household chores. Within this context, men's involvement appears to be stimulated by women's demands (Barnett \& Baruch, 1987).

This paper examines the effects of structural, ideational, interactional, and family process factors on the division of household labor in families with children. Specifically, it identifies patterns and correlates of men's participation in female gender-typed chores. As discussed below, there are several unresolved debates regarding what accounts for certain labor patterns within the home (e.g., relative resources, time availability, ideology, or life course transitions). Our study extends previous research by using a nationally representative sample to explore husband's participation in female gender-typed chores. Many previous studies use smaller, nonrepresentative samples, do not distinguish female from male chores, and consider only total household labor. While our study analyzes the total number of chores performed by husbands, it examines individual chores as well. Moreover, it differentiates between daily and non-daily chores in order to highlight men's involvement in the most nondiscretionary chores typically performed by women. Thus, this research examines the actual nature of work being done by husbands and wives - the quality of household activity - a crucial, yet underexplored dimension of the gender division of labor (Coleman, 1988). 
The present research also has practical significance in that wives are happiest when their husbands share traditionally female chores, regardless of how much time they themselves spend in housework (Benin \& Agostinelli, 1988). Thus, role-sharing may contribute to marital quality and stability. In addition, role-sharing men, by demonstrating competence in both work and family domains, provide valuable role models for their children. Shifting ideologies and behaviors regarding the gender division of household labor reveal that gender is not a static, unchanging characteristic, but rather an evolving, emergent set of orientations, skills, and actions which is sensitive to a variety of environmental, interactional, and psychological influences over the life course (Bronfenbrenner, 1979). Greater rolesharing in housework may partially alter children's and adults' conceptions of chores as either gender-specific or gender-neutral (see Coltrane, 1989).

\section{THEORIES OF HOUSEHOLD LABOR ALLOCATION}

\section{Relative Resources}

Three major theories of labor allocation within the household are power/relative resrouces, time availability, and ideology/socialization. The power or excharge perspective is a primary model for understanding role-sharing (Coltrane \& Ishii-Kuntz, 1990). Relative resources, often referring to imbalances in marital power, are frequently measured by relative income of spouses. Some find female resources to be associated with increased housework by husbands (Model, 1981; Ross, 1987), and wife's earnings and occupational prestige have been linked to more equal divisions of labor (Maret \& Finlay, 1984; Spitze, 1988). Increases in male income are associated with less role sharing, while higher female income is related to more sharing (Antill \& Cotton, 1988). More generally, Rubin (1976) finds that greater female resources reduce gender role traditionalism in marriage.

Nevertheless, others conclude that relative income is unrelated (Farkas, 1976; Huber \& Spitze, 1983) or curvilinearly related (Hochschild, 1989 ) to household labor allocation. $21 \%$ of men who earn more than their wives share housework, $30 \%$ of those who earn about the same, and none of the husbands earning less than their wives. Thus, the "logic of the pocketbook" appears to operate only when men earn as much as or more than their wives. This paradox can be partially understood psychologically as the result of balancing: if men lose power over women in one sphere (such as breadwinning), they make up for it in another (such as housework) (Hochschild, 1989). 
Studies that use education as a measure of relative resources consistently fail to yield results that support exchange theory (Coverman, 1985). Since men's, but not women's education is associated with greater role-sharing (Antill \& Cotton, 1988; Kamo, 1988; Ross, 1987), education is interpreted to be a reflection of socialization or ideology. More education is assumed to reflect more egalitarian beliefs (Berardo et al., 1987; Huber \& Spitze, 1983; Kamo, 1988; Miller and Garrison, 1982; Ross, 1987).

Due to limitations inherent in a structural conception of power, some studies fruitfully analyze interactional dimensions of marital power as well. For example, examining outcomes of marital conflict as indicators of marital power reveals that the more powerful spouse does less domestic work (Kamo, 1988; Hardesty \& Bokemeier, 1989; Kompter, 1989). Thus, the present study adopts a comprehensive definition of power which includes both structural and interactional factors.

\section{Ideology}

Ideology, usually conceived as resulting from socialization, undergirds another theory of household division of labor. Some researchers find a negative relationship between traditional beliefs and family work (Hiller \& Philliber, 1986; Kamo, 1988; Model, 1981; Blair \& Lichter, 1991; Pleck, 1983), while others reach different conclusions (Geerken \& Gove, 1983; Crouter, Perry-Jenkins, Huston, \& McHale, 1987; Coverman, 1985).

When husbands and wives hold different attitudes, the determination of how household tasks will be divided, if at all, is based on their interplay and negotiation. Studies are divided with regard to whose wishes prevail in cases of disagreement. While several studies find that women's attitudes and behavior determine the division of labor (Antill \& Cotton, 1988; Hardesty \& Bokemeier, 1989), others demonstrate that men's attitudes have a greater impact (Ross, 1987). Indeed, husbands' prerogatives continue to have a more pronounced effect on marital role bargains than do wives' employment status or other family characteristics (Hiller \& Philliber, 1986).

Thus, results are inconsistent with respect to women's and men's relative power to influence household process. Taken together, the studies which seek to explain variation in how couples resolve ideological differences suggest that power, time availability, and ideology each plays a role. For instance, when a husband does not work or earns less, is more educated, and has more egalitarian gender-role beliefs, he is more likely to participate in domestic tasks (Kamo, 1988). 
Time Availability

Time availability refers to "free time" apart from hours spent in market labor (Kamo, 1988; Pleck, 1983; Spitze, 1988). It is typically operationalized as employment status or number of hours employed. However, this perspective has not garnered strong support. Associations between husband's time availability and housework are small or inconsistent (Coverman, 1985; Hardesty \& Bokemeier, 1989). Increases in the proportion of housework performed by husbands are frequently due to wives doing less, rather than husbands doing substantially more (Berardo et al., 1987; Pleck, 1985). Several studies find that husbands of employed women spend little or no more time in housework than husbands of nonemployed women (e.g., Fox \& Nickols, 1983; Spitze, 1988; Walker \& Woods, 1976). Furthermore, although some find a positive association between husbands' housework and wives' employment hours (Barnett \& Baruch, 1987; Spitze, 1988; Miller \& Garrison, 1982; Moore \& Hofferth, 1979; Rallings \& Nye, 1979; Szinovacz, 1984), the difference is small (Shelton, 1992).

Another salient dimension of time availability is the amount of household work, often operationalized with reference to the presence or absence, number, and youth of children. Some studies find that more and younger children increase men's level of housework (Farkas, 1976; Berk \& Berk, 1979; Geerken \& Gove, 1983; Pleck, 1985). Results, however, are mixed. Some report (e.g., Perucci, Potter, \& Rhoads, 1978) that husbands contribute more in households with fewer children and do less after children are born (e.g., Cowan, 1988). Others maintain that as family work increases, some husbands help by doing some of the more enjoyable household tasks, such as playing with children while wives prepare meals or clean (Berk \& Berk, 1979; Coleman, 1988).

Life course dynamics are also a factor, as husbands who are older when they have their first child tend to perform more housework (Coltrane \& Ishii-Kuntz, 1990). The reasons for this include more liberal ideology, a stronger desire to embrace completely the father role, and a greater likelihood of having an employed wife with an egalitarian orientation. Thus, men's ideology is a stronger explanation for role-sharing among fathers who become parents in their late twenties or later, while power is a more compelling factor for men who become fathers earlier. As for other demographic factors, older couples tend to have a more traditional division of labor (Antill \& Cotton, 1988) and blacks have a more egalitarian division of labor than whites (Lewis, 1975). 


\section{ANALYSIS PLAN AND HYPOTHESES}

This paper focuses principally upon the relative importance of power, time availability, ideology, and life course factors in explaining household labor allocation. Importantly, we examine both structural and interactional dimensions of marital power in order to understand how socioeconomic and interpersonal resources affect role-sharing (Safilios-Rothschild, 1976). Our first goal is to ascertain men's level of involvement in female-typed chores. Second, multivariate regression models (logistic and OLS) are presented for individual and total chores to evaluate the relative importance of predictor variables. As discussed below, the regression analyses include both main and interactive effects.

In light of previous studies, we expected to find that division of labor is largely gender-typed and that relative resources, ideology, time availability, and age at first birth would most strongly explain men's contributions. Background factors should explain very little. In particular, we predicted that men's cross-gender housework would be related to women's employment, greater relative earnings, liberal gender ideology, and involvement in decision-making, as well as husband's education, age at first birth, number of children, and African-American descent. We also expected that there would be an interaction between women's contribution to family income and their gender role attitudes and family decision-making.

\section{DATA}

We analyze data from Wave 2 of the National Survey of Children (1981). The sample consists of a nationally representative sample of about 2,000 children 11 to 16 years of age and one parent (generally the mother). Blacks were oversampled to enable more meaningful analyses of this group; the sample was reweighted to reflect more accurately the U.S. population (for further information, see Furstenberg, Peterson, Nord, \& Zill, 1983). The subsample for our analyses consists of 1,004 married-couple families. We examined only married-couple families because they differ from cohabitors with regard to household division of labor (Shelton \& John, 1990). Cohabitors are not within the scope of this paper.

This survey is particularly useful for our purposes because it provides data on families with children. Since there is often more housework in such families, we are able to study the household division of labor in one family structure in which women generally have more family work. We are also able to consider housework within the broader context of number of children, father's age at first birth, parenting style, and family climate (e.g., 
father-child closeness). Furthermore, since wives usually do most of the extra housework when children are present (Shelton, 1992), it is particularly important to identify predictors of men's household labor for this family type. In addition, focusing on families with older children is useful in that it enables one to detect gender differences after the most intensive period of child care is past. Since many otherwise egalitarian couples believe that mothers are more important for children in the early years (and since breastfeeding is a uniquely female activity), families with young children might not be highly representative of all families with children.

\section{Operationalization of Variables}

Dependent Variables. Dependent variables measure husbands' involvement in four frequently performed female gender-typed chores: a) cooking; b) washing dinner dishes; c) grocery shopping; and d) cleaning house. These chores were selected for two reasons. First, they have high face validity as measures of female gender-typed chores. They resonate with hegemonic social and cultural expectations and experiences regarding how labor is divided in the home. Second, distributions show that women perform them well over half of the time.

Respondents were asked: "Who, if anyone, usually cooks, does the grocery shopping, cleans the house, and does the evening dishes?" The variables were dichotomized to reflect whether men contribute substantially in these areas. Inclusion of the word 'usually' is important because it enables us to distinguish husbands who perform female gender-typed chores on an occasional basis (e.g., during illness, family emergency, etc.) from those who do so on a rather regular basis. Therefore, this measure is a very good indicator of rolesharing with regard to female gender-typed household labor.

Significantly, there is variation with regard to how often these chores are performed. Cooking and washing dishes are typically performed daily, while grocery shopping and cleaning are usually done on a weekly or non-daily basis. The distinction between daily and non-daily is crucial to a full understanding of role-sharing within families because couples with an otherwise egalitarian division of labor often diverge in this regard (Hochschild, 1989).

Among couples who share family work rather equitably, women do two-thirds of the daily work, thus fixing them into a more rigid routine. In contrast, men's work is often performed over the weekend, thereby having a smaller negative effect on the amount of time available for paid labor. Each hour spent on household labor means 55 minutes less that women devote to paid labor, but only 40 minutes less for men (Shelton \& Firestone, 1988). This is probably the case because women's chores are less discretionary in terms of when they must be performed. 
These measures of housework have strengths and weaknesses compared to those of time-use studies. Time-use studies generally use time diary measures. Previous research has shown that estimates of time use based on direct questions yield higher estimates than those based on time diaries. In addition, although time diary data are good indicators of actual time use, another limitation is that they may underestimate time spent on some activities. For instance, time diary estimates are likely to underestimate women's household labor time because respondents are apt to omit small segments of time spend on household tasks (e.g., 5 minutes straightening the living room). On the other hand, study participants may be less likely to overestimate their "usual" time spent on activities. A third drawback of these measures is that tasks which occur infrequently, but occupy a large block of time, could be missed with time diary measures (Shelton, 1992).

Note that unavailability of self-report data from men does not appear to compromise the reliability of our estimates. This is the case for several reasons. First, self reports are often subject to systematic error (Glandon, Counte, \& Tancredi, 1992). Second, discrepancies between husband and wife reports are typically slight at the aggregate level. Third, discrepancies within husband and wife pairs are thought to arise as a result of the ambiguity inherent in some questions (Olson \& Cromwell, 1975). Given the centrality of the examined chores to household routine, difficulty in recollection or other confusion is less likely to be problematic than it would be with regard to questions about less concrete, more complicated domains of marital interaction such as authority and decision-making. Monroe, Bokemeier, Kotchen, \& McKean (1985) find significant spousal response consistency for all task-allocation and decision-making items.

Fourth, incongruous findings regarding vanity versus modesty biases raise doubts about the reliability of self-report measures and suggest potential biases in reports from only one spouse (Douglas \& Wind, 1978). Harris and Gilbert (1987) found that a much larger percentage of husbands than wives report sharing responsibility for what have traditionally been female tasks. Coleman (1988) similarly observes that husbands define their involvement in the most egalitarian terms possible, thus introducing measurement error due to vanity (or social desirability) bias. Fifth, comparisons of husbands' and wives' self reports across measurement strategies reveal that wives' contributions to housework are invariably higher and that crossmethod comparisons yield more consistency in wives' than husbands' reports (Warner, 1986). Thus, husbands and wives give rather similar assessments of who does the housework, and husbands' reports are more prone to measurement error than wives' reports. 
Independent Variables. The more structural dimension of marital power, that relating to relative economic resources, is measured by wife's contribution to income (coded as none, less than half, more than half, or all). Interactional marital power/authority is operationalized as final say in decision-making when there is disagreement. This is a reliable, frequently used indicator of authority in marriage (see, for example, Berk, 1985; Blood $\&$ Wolfe, 1960), and most consistent with the way power has been conceptualized in sociology (Blumstein \& Schwartz, 1991).

Measures of time availability are wife's employment status (none, parttime, and full-time) and number of children. Socialization/ideology is operationalized by a three-item additive scale for wife's gender role attitudes (husband's attitudes are unavailable) and husband's and wife's education (less than high school, high school graduate, college graduate). With regard to gender role attitudes, respondents were asked how strongly they agree with the following statements (alpha $=.68$ ): "Marriages are better when the husband works and the wife runs the home and cares for the children," "Children are better off if their mothers do not work outside the home," and "Working women make more interesting partners in marriage."3

Husband's age at first birth, family income, race, and husband's number of marriages provide a life course and demographic context in which to better understand household labor allocation. Number of marriages is included because previous research suggests that subsequent marriages are more egalitarian than first marriages (Furstenberg, 1982). Gross family income categories are less than $\$ 10,000, \$ 10-19,999, \$ 20-34,999, \$ 35-49,999$, and $\$ 50,000$ or over. In order to determine the condition under which wives' earnings affects husbands' housework, three interaction terms were created: 1) wives' earnings by family income; 2) wives' earnings by gender attitudes; and 3) wives' earnings by decision-making.

Finally, several variables reflective of family climate and parenting style are included to examine the effects of interactional as well as structural family conditions. Wife's marital satisfaction is considered since it is related to men's involvement in family work (Starrels, 1994; Harris \& Morgan, 1991). Respondents were asked, "Would you say that your marriage is not too happy, fairly happy, or very happy?" We also examine fathers' closeness to children to determine whether fathers display consistency across different spheres of family work. Closeness is an additive scale constructed from z-scores for child's and mother's reports of closeness to father, how much child wants to be like father, shared enjoyable activities, and confiding (alpha is .73).

\footnotetext{
${ }^{3}$ Note that there may be a problem of endogeneity between independent variables such as gender role attitudes and outcomes including household chores. Although this is not within the scope of this paper, further research might profitably address the question of endogeneity more fully.
} 
Democratic parenting was included to ascertain whether there are links between egalitarian orientations toward children and egalitarian approaches to marriage. An additive index is comprised of the following questions asked of the child: 1) How much say do you have in making up family rules (little or none, some, a lot)? 2) Do your parents often, sometimes, or hardly ever talk over important decisions with you?, and 3) listen to your side of an argument?

\section{RESULTS}

\section{Level of Husbands' Involvement}

Table I shows that most couples exhibit a traditional gender division of household labor. Mean number of chores performed by men is .86 . Over a half of the husbands $(54 \%)$ do none of these chores, about a fifth $(21 \%)$ do one chore, $13 \%$ perform two, $8 \%$ are involved in three, and $3 \%$ perform all four. With regard to specific chores, $19 \%$ of men share cooking, $17 \%$ dinner dishes (in a third of the households children perform this chore), $21 \%$ cleaning, and $29 \%$ food shopping. Note the tendency for husbands to be more involved in non-daily chores, particularly food shopping.

The low level of husbands' involvement overall may be partially explained by the nature of the subsample. Since respondents are in families with at least one child in early or middle adolescence, the couples are likely to have more traditional gender roles than could be expected among all married couples. Previous studies demonstrate that husbands' labor force activity increases when they have at least one child. Greater labor force activity, in turn, reduces the available time for housework. In addition, for white married respondents, becoming a parent encourages more traditionalism (Morgan \& Waite, 1987).

\section{Description of Sample}

Table I also shows the characteristics of the sample with respect to independent variables. Wives report having substantial decision-making authority in their marriages. On average, they contribute less than half of the family income and are employed part-time. Mean number of children is 2.9. Their gender role attitudes are slightly more traditional than average. Men's education is slightly higher than women's, although they both average a little less than 12 years. Husbands typically had their first child 
Table I. Descriptive Statistics for Dependent and Independent Variables ${ }^{a}$

\begin{tabular}{lrrc}
\hline Variable & Mean & SD & Range \\
\hline Cooks & .19 & .39 & $0-1$ \\
Dishes & .17 & .37 & $0-1$ \\
Cleans & .21 & .41 & $0-1$ \\
Shops & .29 & .45 & $0-1$ \\
Total chores & .86 & 1.13 & $0-4$ \\
Decisions & 1.94 & .45 & $1-3$ \\
Wife's earnings & 1.76 & .63 & $1-4$ \\
Work status & .97 & .91 & $0-2$ \\
No. children & 2.92 & 1.34 & $1-11$ \\
Gender attitudes & 2.59 & .97 & $1-5$ \\
Wife's education & 1.87 & .63 & $1-3$ \\
Husband's education & 1.93 & .66 & $1-3$ \\
Husband's age at first birth & 26.85 & 7.03 & $13-60$ \\
Husband's no. marriages & 1.23 & .53 & $1-5$ \\
Race & .11 & .31 & $0-1$ \\
Income & 2.70 & .94 & $1-5$ \\
Husband's closeness & .00 & .69 & $-1.79-1.30$ \\
Democracy & 2.10 & .53 & $1-3$ \\
Wife's marital satisfaction & 2.62 & .56 & $1-3$ \\
\hline
\end{tabular}

${ }^{a} N=1,044$.

at about 27 years and had 1.2 marriages. Although Blacks were oversampled, $9 \%$ of the sample is Black after weighting data and $2 \%$ Hispanic and Asian. Average family income is roughly $\$ 20,000$. Parental democracy is slightly higher than average, and wives' martial satisfaction is high. (See also Table II for correlations between dependent and independent variables.)

\section{Correlates of Husbands' Involvement}

Multivariate Analyses. Table III presents OLS and logistic regression results (main effects) for cooking, doing dishes, cleaning, grocery shopping, and an index of total number of chores which husbands share on a regular basis. Wife's earnings, employment, liberal gender role attitudes, age at first birth, and marital satisfaction are positively related to three of the five dependent variables. Overall, the findings support power, time availability, and socialization theories of the division of household labor and are consistent with previous findings that life course and family process factors should be taken into account. 


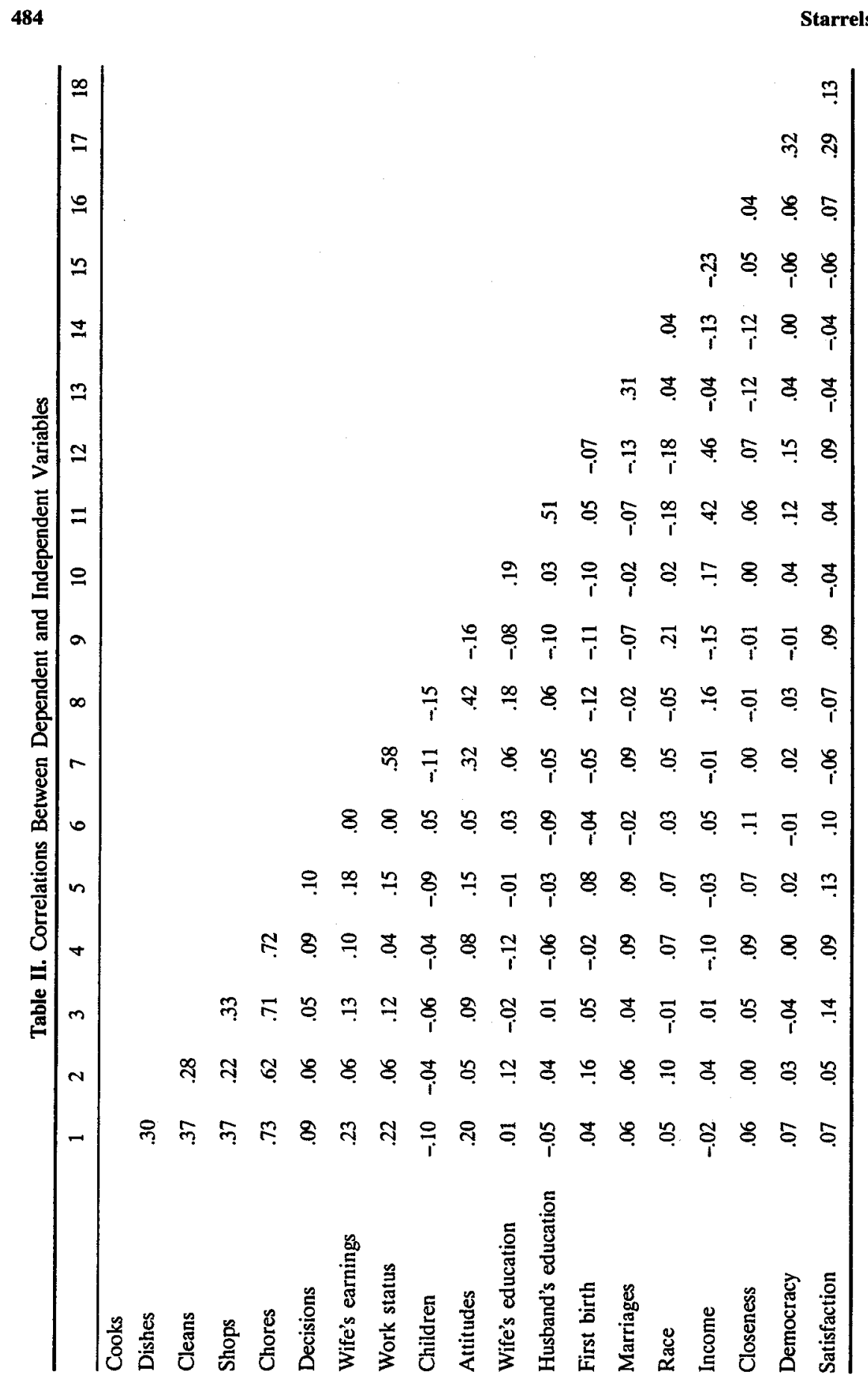


Table III. Logistic and OLS Regression Models of Individual and Total Chores: Main Effects

\begin{tabular}{|c|c|c|c|c|c|c|}
\hline \multirow[b]{2}{*}{ Independent Variables } & \multirow{2}{*}{$\begin{array}{c}\text { Cook } \\
b \\
(\mathrm{SE}) \\
\end{array}$} & \multirow{2}{*}{$\begin{array}{c}\text { Dishes } \\
b \\
(\mathrm{SE})\end{array}$} & \multirow{2}{*}{$\begin{array}{c}\text { Clean } \\
b \\
(\mathrm{SE}) \\
\end{array}$} & \multirow{2}{*}{$\begin{array}{c}\text { Shop } \\
b \\
\text { (SE) }\end{array}$} & \multicolumn{2}{|c|}{ Total } \\
\hline & & & & & $\begin{array}{c}b \\
(\mathrm{SE})\end{array}$ & Beta \\
\hline Decisions & $\begin{array}{c}.37 \\
(.22)\end{array}$ & $\begin{array}{c}.26 \\
(.24)\end{array}$ & $\begin{array}{c}.18 \\
(.22)\end{array}$ & $\begin{array}{c}.26 \\
(.19)\end{array}$ & $\begin{array}{c}.16 \\
(.09)\end{array}$ & .06 \\
\hline Wife's earnings & $\begin{array}{r}.43^{a} \\
(.18)\end{array}$ & $\begin{array}{r}.38^{a} \\
(.19)\end{array}$ & $\begin{array}{c}.32 \\
(.18)\end{array}$ & $\begin{array}{c}.29 \\
(.16)\end{array}$ & $\begin{array}{r}.21^{b} \\
(.08)\end{array}$ & .12 \\
\hline Work status & $\begin{array}{r}.43^{b} \\
(.13)\end{array}$ & $\begin{array}{c}.11 \\
(.14)\end{array}$ & $\begin{array}{r}.27^{a} \\
(.13)\end{array}$ & $\begin{array}{c}.06 \\
(.12)\end{array}$ & $\begin{array}{r}.12^{a} \\
(.06)\end{array}$ & .09 \\
\hline Number of children & $\begin{array}{l}-.12 \\
(.08)\end{array}$ & $\begin{array}{r}-.24^{b} \\
(.09)\end{array}$ & $\begin{array}{l}-.09 \\
(.08)\end{array}$ & $\begin{array}{l}-.03 \\
(.07)\end{array}$ & $\begin{array}{l}-.06 \\
(.03)\end{array}$ & -.07 \\
\hline Gender attitudes & $\begin{array}{r}.29^{b} \\
(.10)\end{array}$ & $\begin{array}{c}.08 \\
(.11)\end{array}$ & $\begin{array}{c}.14 \\
(.10)\end{array}$ & $\begin{array}{r}.22^{a} \\
(.09)\end{array}$ & $\begin{array}{r}.12^{b} \\
(.04)\end{array}$ & .10 \\
\hline Women's education & $\begin{array}{l}-.06 \\
(.19)\end{array}$ & $\begin{array}{r}.55^{b} \\
(.20)\end{array}$ & $\begin{array}{l}-.38^{a} \\
(.18)\end{array}$ & $\begin{array}{l}-.76^{b} \\
(.17)\end{array}$ & $\begin{array}{c}-.14 \\
(.08)\end{array}$ & -.08 \\
\hline Men's education & $\begin{array}{l}-.02 \\
(.18)\end{array}$ & $\begin{array}{c}.08 \\
(.19)\end{array}$ & $\begin{array}{c}.30 \\
(.18)\end{array}$ & $\begin{array}{c}.20 \\
(.16)\end{array}$ & $\begin{array}{c}.09 \\
(.07)\end{array}$ & .05 \\
\hline Age at first birth & $\begin{array}{c}.01 \\
(.02)\end{array}$ & $\begin{array}{r}.04^{b} \\
(.02)\end{array}$ & $\begin{array}{c}.03^{a} \\
(.01)^{a}\end{array}$ & $\begin{array}{c}.00 \\
(.01)\end{array}$ & $\begin{array}{r}.01^{a} \\
(.01)\end{array}$ & .08 \\
\hline Number of marriages & $\begin{array}{c}.16 \\
(.18)\end{array}$ & $\begin{array}{c}.25 \\
(.18)\end{array}$ & $\begin{array}{c}.06 \\
(.17)\end{array}$ & $\begin{array}{c}.22 \\
\left(.16^{a}\right)\end{array}$ & $\begin{array}{c}.15 \\
(.08)\end{array}$ & .07 \\
\hline Race & $\begin{array}{c}.49 \\
(.33)\end{array}$ & $\begin{array}{c}.51 \\
(.37)\end{array}$ & $\begin{array}{l}-.07 \\
(.36)\end{array}$ & $\begin{array}{c}.17 \\
(.31)\end{array}$ & $\begin{array}{c}.18 \\
(.15)\end{array}$ & .04 \\
\hline Income & $\begin{array}{l}-.15 \\
(.12)\end{array}$ & $\begin{array}{c}.02 \\
(.13)\end{array}$ & $\begin{array}{l}-.05 \\
(.11)\end{array}$ & $\begin{array}{l}-.17 \\
(.10)\end{array}$ & $\begin{array}{l}-.06 \\
(.05)\end{array}$ & -.05 \\
\hline Closeness & $\begin{array}{c}.17 \\
(.15)\end{array}$ & $\begin{array}{l}-.09 \\
(.16)\end{array}$ & $\begin{array}{c}.11 \\
(.15)\end{array}$ & $\begin{array}{r}.43^{b} \\
(.14)\end{array}$ & $\begin{array}{c}.12 \\
(.06)\end{array}$ & .07 \\
\hline Democracy & $\begin{array}{c}.26 \\
(.19)\end{array}$ & $\begin{array}{c}.22 \\
(.20)\end{array}$ & $\begin{array}{l}-.43^{a} \\
(.18)\end{array}$ & $\begin{array}{l}-.05 \\
(.17)\end{array}$ & $\begin{array}{l}-.01 \\
(.08)\end{array}$ & .00 \\
\hline Marital satisfaction & $\begin{array}{r}.38^{a} \\
(.18)\end{array}$ & $\begin{array}{c}.27 \\
(.19)\end{array}$ & $\begin{array}{r}.97^{b} \\
(.20)\end{array}$ & $\begin{array}{r}.32^{a} \\
(.16)\end{array}$ & $\begin{array}{r}.27^{b} \\
(.07)\end{array}$ & .13 \\
\hline Constant & -5.52 & -6.39 & -5.01 & -2.25 & -1.11 & \\
\hline$\chi^{2} / \mathbf{R}^{2}$ & 844.98 & 808.43 & 830.04 & 831.75 & .11 & \\
\hline$\left(p\right.$ for $\left.\chi^{2}\right)$ & .24 & .58 & .37 & .36 & - & \\
\hline
\end{tabular}

${ }^{a}$ Significant at .05 level.

${ }^{b}$ Significant at .01 level. 
More specifically, total chores is predicted by wife's income contribution, employment status, gender role attitudes, age at first birth, and marital satisfaction. Sharing responsibility for cooking is associated with income contribution, work status, attitudes, and marital satisfaction. Doing the evening dishes is related to income contribution, fewer children, wife's lower education, and age at first birth. Cleaning is explained by work status, wife's lower education, age at first birth, less democratic parenting styles, and marital satisfaction. Finally, shopping for groceries is predicted by attitudes, wife's lower education, father-child closeness, and marital satisfaction.

Overall, wife's contribution to income, employment status, gender attitudes, marital satisfaction, and husband's age at first birth are the strongest correlates of husbands' cross-gender housework. Wife's relative income is the strongest predictor of men's involvement in daily tasks. The strong associations between marital satisfaction and husbands' cleaning and total number of chores suggests that satisfaction may be an outcome rather than or in addition to a predictor (see also Harris \& Morgan, 1991).

Table IV shows OLS and logistic regression results for the interactive model. The interaction between wife's earnings and gender-role attitudes is significantly related to cooking, cleaning, shopping, and total chores. That is, wife's contribution to family income has a greater effect on these housework measures when her attitudes are more liberal. Similarly, a wife's liberal attitudes are more often associated with her husband's cooking, cleaning, shopping, and total chores when she contributes a larger share of the household income.

In addition, the interaction between wife's earnings and decisionmaking is positively associated with cooking. Again, wife's income contribution has a more powerful effect on husband's cooking when she has more decision-making authority. In a similar fashion, her decision-making exerts a greater influence on cooking when she contributes a larger share of the household income.

\section{SUMMARY AND CONCLUSION}

Using data from the National Survey of Children, we examine the division of household labor in married-couple families with children in early to middle adolescence. In sum, power, time availability, socialization, and life course perspectives all garner support, and family process is a significant factor as well. The vast majority of women perform female household chores. Only about one-fifth of husbands are involved fully in these activities. 
Table IV. Logistic and OLS Regression Models of Individual and Total Chores: Main and

\begin{tabular}{|c|c|c|c|c|c|c|}
\hline \multirow[b]{2}{*}{ Independent Variables } & \multirow{2}{*}{$\begin{array}{c}\text { Cook } \\
b \\
\text { (SE) }\end{array}$} & \multirow{2}{*}{$\begin{array}{c}\text { Dishes } \\
b \\
(\mathrm{SE})\end{array}$} & \multirow{2}{*}{$\begin{array}{c}\text { Clean } \\
b \\
(\mathrm{SE})\end{array}$} & \multirow{2}{*}{$\begin{array}{c}\text { Shop } \\
b \\
\text { (SE) }\end{array}$} & \multicolumn{2}{|c|}{ Total } \\
\hline & & & & & $\begin{array}{c}b \\
(\mathrm{SE}) \\
\end{array}$ & Beta \\
\hline Decisions & $\begin{array}{c}-1.39 \\
(.76)\end{array}$ & $\begin{array}{l}-.13 \\
(.76)\end{array}$ & $\begin{array}{c}.05 \\
(.69)\end{array}$ & $\begin{array}{l}-.21 \\
(.59)\end{array}$ & $\begin{array}{l}-.25 \\
(.26)\end{array}$ & -.10 \\
\hline Wife's earnings & $\begin{array}{r}-2.02^{a} \\
(.97)\end{array}$ & $\begin{array}{l}-.28 \\
(.97)\end{array}$ & $\begin{array}{r}-1.25 \\
(.92)\end{array}$ & $\begin{array}{r}-1.56^{a} \\
(.79)\end{array}$ & $\begin{array}{l}-.85 \\
(.35)\end{array}$ & $-.46^{a}$ \\
\hline Work status & $\begin{array}{r}.49^{b} \\
(.14)\end{array}$ & $\begin{array}{l}.14 \\
(.15)\end{array}$ & $\begin{array}{l}.33^{b} \\
(.14)\end{array}$ & $\begin{array}{c}.06 \\
(.12)\end{array}$ & $\begin{array}{l}.14 \\
(.06)\end{array}$ & $.11^{b}$ \\
\hline Number of children & $\begin{array}{l}-.12 \\
(.08)\end{array}$ & $\begin{array}{l}-.24^{b} \\
(.09)\end{array}$ & $\begin{array}{l}-.09 \\
(.08)\end{array}$ & $\begin{array}{l}-.02 \\
(.07)\end{array}$ & $\begin{array}{l}-.05 \\
(.03)\end{array}$ & -.06 \\
\hline Gender attitudes & $\begin{array}{l}-.53 \\
(.36)\end{array}$ & $\begin{array}{l}-.35 \\
(.37)\end{array}$ & $\begin{array}{r}-1.14^{b} \\
(.35)\end{array}$ & $\begin{array}{l}-.57^{a} \\
(.29)\end{array}$ & $\begin{array}{l}-.45 \\
(.14)\end{array}$ & $-.38^{b}$ \\
\hline Wife's education & $\begin{array}{l}-.09 \\
(.19)\end{array}$ & $\begin{array}{l}.55^{b} \\
(.21)\end{array}$ & $\begin{array}{l}-.40^{a} \\
(.18)\end{array}$ & $\begin{array}{l}-.78^{b} \\
(.17)\end{array}$ & $\begin{array}{l}-.15 \\
(.08)\end{array}$ & $-.08^{a}$ \\
\hline Husband's education & $\begin{array}{l}-.04 \\
(.19)\end{array}$ & $\begin{array}{c}.05 \\
(.19)\end{array}$ & $\begin{array}{c}.26 \\
(.18)\end{array}$ & $\begin{array}{c}.18 \\
(.16)\end{array}$ & $\begin{array}{c}.07 \\
(.07)\end{array}$ & .04 \\
\hline Age at first birth & $\begin{array}{c}.01 \\
(.02)\end{array}$ & $\begin{array}{r}.04^{a} \\
(.02)\end{array}$ & $\begin{array}{r}.04^{b} \\
(.01)\end{array}$ & $\begin{array}{c}.01 \\
(.01)\end{array}$ & $\begin{array}{c}.01 \\
(.01)\end{array}$ & $.09^{a}$ \\
\hline Number of marriages & $\begin{array}{c}.16 \\
(.18)\end{array}$ & $\begin{array}{c}.24 \\
(.19)\end{array}$ & $\begin{array}{c}.05 \\
(.18)\end{array}$ & $\begin{array}{c}.24 \\
(.16)\end{array}$ & $\begin{array}{c}.14 \\
(.08)\end{array}$ & .07 \\
\hline Race & $\begin{array}{c}.56 \\
(.34)\end{array}$ & $\begin{array}{c}.52 \\
(.38)\end{array}$ & $\begin{array}{c}.05 \\
(.36)\end{array}$ & $\begin{array}{c}.24 \\
(.31)\end{array}$ & $\begin{array}{c}.21 \\
(.15)\end{array}$ & .05 \\
\hline Income & $\begin{array}{c}.35 \\
(.32)\end{array}$ & $\begin{array}{c}.27 \\
(.30)\end{array}$ & $\begin{array}{c}.17 \\
(.28)\end{array}$ & $\begin{array}{l}-.35 \\
(.26)\end{array}$ & $\begin{array}{c}.08 \\
(.11)\end{array}$ & .06 \\
\hline Closeness & $\begin{array}{l}.15 \\
(.16)\end{array}$ & $\begin{array}{l}-.10 \\
(.16)\end{array}$ & $\begin{array}{l}.10 \\
(.15)\end{array}$ & $\begin{array}{r}.44^{b} \\
(.14)\end{array}$ & $\begin{array}{l}.11 \\
(.06)\end{array}$ & .06 \\
\hline Democracy & $\begin{array}{c}.29 \\
(.19)\end{array}$ & $\begin{array}{c}.23 \\
(.20)\end{array}$ & $\begin{array}{l}-.42^{a} \\
(.19)\end{array}$ & $\begin{array}{l}-.02 \\
(.17)\end{array}$ & $\begin{array}{c}.00 \\
(.08)\end{array}$ & .00 \\
\hline Marital satisfaction & $\begin{array}{r}.40^{a} \\
(.19)\end{array}$ & $\begin{array}{c}.28 \\
(.19)\end{array}$ & $\begin{array}{l}1.01^{b} \\
(.20)\end{array}$ & $\begin{array}{r}.32^{a} \\
(.16)\end{array}$ & $\begin{array}{c}.28 \\
(.07)\end{array}$ & $.14^{b}$ \\
\hline Wife's earnings $\times$ income & $\begin{array}{l}-.26 \\
(.16)\end{array}$ & $\begin{array}{l}-.14 \\
(.15)\end{array}$ & $\begin{array}{l}-.12 \\
(.15)\end{array}$ & $\begin{array}{l}.11 \\
(.14)\end{array}$ & $\begin{array}{l}-.07 \\
(.06)\end{array}$ & -.15 \\
\hline Wife's earnings $\times$ attitudes & $\begin{array}{r}.44^{a} \\
(.18)\end{array}$ & $\begin{array}{l}.23 \\
(.18)\end{array}$ & $\begin{array}{r}.67^{b} \\
(.17)\end{array}$ & $\begin{array}{r}.43^{b} \\
(.15)\end{array}$ & $\begin{array}{c}.31 \\
(.07)\end{array}$ & $.75^{b}$ \\
\hline Wife's earnings $\times$ decisions & $\begin{array}{r}.97^{a} \\
(.40)\end{array}$ & $\begin{array}{c}.22 \\
(.40)\end{array}$ & $\begin{array}{c}.09 \\
(.37)\end{array}$ & $\begin{array}{c}.29 \\
(.32)\end{array}$ & $\begin{array}{c}.24 \\
(.14)\end{array}$ & .30 \\
\hline Constant & -1.16 & -5.23 & -2.47 & .92 & .69 & - \\
\hline$-2 \mathrm{LL}$ & 730.02 & 674.40 & 773.06 & 908.26 & - & \\
\hline $\mathbf{R}^{2}(F)$ & - & - & - & - & .13 & $\left(7.09^{b}\right)$ \\
\hline
\end{tabular}

${ }^{a}$ Significant at .05 level.

${ }^{b}$ Significant at .01 level. 
Multivariate models reveal that structural and ideational variables with respect to women (employment, earnings, and ideology) have the greatest overall impact, although relative earnings is the strongest predictor of daily chores. Moreover, the robust interactive effect between a wife's contribution to family income and her gender role attitudes suggests an interactive effect between resource levels and socialization. In addition, the more limited interactive effect between wife's income contribution and her decision-making authority demonstrates the interplay between formal and informal power.

As discussed above, previous research has been inconsistent with regard to the effect of women's resources. However, the present results are consistent with most of the studies, especially those more recent and those based on larger samples. This study also reports stronger effects of women's employment status (i.e., for cooking, cleaning, and total chores) than most previous studies. These results may differ from previous findings for several reasons.

First, this study examines individual and total chores in terms of whether husbands perform them on a regular basis. Other studies often use total hours of household labor (and often do not distinguish among specific chores). Second, whereas employment status is often measured as total work hours, the present study uses an ordinal measure. Third, this study is based on families with children, whereas most previous studies are not. One potential basis of these data is that the effect of women's labor force activity might be enhanced because children necessitate more housework. That is, in dual-earner families, husbands with children may do more housework than their counterparts without children simply because children create more housework.

The above results have important theoretical implications. First, they strongly confirm the resource theory of household labor allocation. They similarly confirm the socialization perspective, which some studies have discredited. Moreover, this study demonstrates important interactive effects between predictors, thus suggesting the need for synthesis among various theoretical perspectives on the division of household labor.

Future research should further delineate the relative contributions of different factors, with particular attention to specifying their possible interactions and the conditions under which they have a differential impact. Life course factors may be a particularly fertile area for exploration. The present findings are consistent with other studies that reveal an association between a father's age at first birth and his level of involvement in various dimensions of family work (Coltrane \& Ishii-Kuntz, 1990; Starrels, 1994). As we learn more about who does what labor in the household, and why such patterns exist, we may better be able to eliminate women's second shift, create more balanced daily routines for men, and establish work-family interfaces which best prepare our children for adulthood. 


\section{REFERENCES}

Antill, J., \& Cotton, S. (1988). Factors affecting the division of labor in households. Sex Roles, $18,531-553$.

Barnett, R., \& Baruch, G. (1987). Determinants of fathers' participation in family work. Journal of Marriage and Family, 49, 29-40.

Benin, M. H., \& Agostinelli, J. (1988). Husbands' and wives' satisfaction with the division of labor. Journal of Marriage and Family, 50, 349-361.

Berardo, D. H., Shehan, C. L., \& Leslie, G. R. (1987). A residue of tradition: Jobs, careers and spouses' time in housework. Joumal of Marriage and Family, 49, 381-390.

Berk, S. (1985). The gender factory. Plenum Press: New York.

Berk, R., \& Berk, S. F. (1979). Labor and leisure at home: Content and organization of the household day. Beverly Hills, CA: Sage.

Blair, S. L., \& Lichter, D. T. (1991). Measuring the division of household labor: Gender segregation of housework among American couples. Journal of Family Issues, 12, 91-113.

Blood, R. O., \& Wolfe, D. M. (1960). Husbands and wives. Glencoe, IL: Free Press.

Blumstein, P., \& Schwartz, P. (1991). Money and ideology. Their impact on power and the division of household labor. In R. L. Blumberg (Ed.), Gender, family, and economy: The triple overlap. Newbury Park, CA: Sage.

Bryson, R., Bryson, J., Licht, M., \& Licht, B. (1976). The professional pair: Husband and wife psychologists. American Psychologist, 31, 10-16.

Bronfenbrenner, U. (1979). The ecology of human development: Experiments by nature and design. Cambridge, MA: Harvard University Press.

Coleman, M. T. (1988). The division of household labor: Suggestions for future empirical consideration and theoretical development. Journal of Family Issues, 9, 132-148.

Coltrane, S. (1989). Household labor and the routine production of gender. Social Problems, $36,473-490$.

Coltrane, S., \& Ishii-Kuntz, M. (1990, August 11-15). Men's housework: A life course perspective. Paper presented at the annual meeting of the American Sociological Association, Washington, DC.

Condran, J., \& Bode, J. (1982). Rashomon, working wives, and family division of labor: Middletown, 1980. Journal of Marriage and Family, 44, 421-426.

Coverman, S. (1985). Explaining husband's participation in domestic labor. The Sociological Quarterly, 26, 81-97.

Cowan, P. A. (1988). Becoming a father: A time of change, an opportunity for development. In P. Bronstein \& C. P. Cowan (Eds.), Fatherhood today: Men's changing role in the family. New York: Wiley.

Crouter, A., Perry-Jenkins, M., Huston, T., \& McHale, S. (1987). Processes underlying father involvement in dual-earner and single-earner families. Developmental Psychology, 23, 431-440.

Douglas, S. P., \& Wind, Y. (1978). Examining family role and authority patterns: Two methodological issues. Joumal of Marriage and Family, 40, 35-47.

Farkas, G. (1976). Education, wage rates, and the division of labor between husband and wife. Journal of Marriage and Family, 38, 473-483.

Fienberg, S. E. (1977). The analysis of cross-classified categorical data. Cambridge, MA: MIT Press.

Fox, K. D., \& Nickols, S. Y. (1983). The time crunch: Wife's employment and family work. Journal of Family Issues, 4, 61-82.

Furstenberg, F. F., Jr. (1982). Conjugal succession: Reentering marriage after divorce. In B. P. Baltes \& O. G. Brim, Jr. (Eds.), Life-span development and behavior (Vol. 4). New York: Academic Press.

Furstenberg, F. F., Jr., Peterson, J. L., Nord, C. W., \& Zill, N. (1983). The life course of children of divorce: Marital disruption and parental contact. American Sociological Review, 48, 656-668. 
Geerken, M., \& Gove, W. (1983). At home and at work: The family's allocation of labor. Beverly Hills, CA: Sage.

Glandon, G. L., Counte, M. A., and Tancredi, D. (1992). An analysis of physician utilization by elderly persons: Systematic differences between self-report and archival information. Journal of Gerontology, 47, S245-S252.

Goodman, L. A. (1979). Simple models for the analysis of association in cross-classifications having ordered categories. Journal of the American Statistical Association, 74, 537-552.

Hardesty, C., \& Bokemeier, J. (1989). Finding time and making do: Distribution of household labor in nonmetropolitan marriages. Journal of Marriage and Family, 51, 253-267.

Harris, L., \& Gilbert, G. (1987). The Phillip Morris family survey. New York: Richard Weiner.

Harris, K. M., \& Morgan, S. P. (1991). Fathers, sons and daughters: Differential paternal involvement in parenting. Journal of Marriage and the Family, 53, 531-544.

Hiller, D., \& Philliber, W. (1986). The division of labor in contemporary marriage: Expectations, perceptions, and performance. Social Problems, 33, 191-201.

Hochschild, A. (1989). The second shift. New York: Viking Penguin.

Huber, J., \& Spitze, G. (1983). Sex stratification: Children, housework, and jobs. New York: Academic Press.

Kamo, Y. (1988). Determinants of household division of labor. Journal of Family Issues, 9, 177-200.

Kompter, A. (1989). Hidden power in marriage. Gender and Society, 3, 187-216.

Lewis, D. K. (1975). The black family: Socialization and sex roles. Phylon, 36, 221-237.

Maret, E., \& Finlay, B. (1984). The distribution of household labor among women in dual-earner families. Journal of Marriage and Family, 46, 357-364.

Miller, J., \& Garrison, H. H. (1982). Sex roles: The division of labor at home and in the workplace. Annual Review of Sociology, 8, 237-262.

Model, S. (1981). Housework by husbands: Determinants and implications. Journal of Family Issues, 2, 225-237.

Moore, K. A., \& Hofferth, S. (1979). Effects of women's employment on marriage. Marriage and Family Review, 2, 27-36.

Morgan, S. P., \& Waite, L. J. (1987). Parenthood and the attitudes of young adults. American Sociological Review, 52, 541-547.

Olson, D. H., \& Cromwell, R. E. (1975). Methodological issues in family power. In R. E. Cromwell \& D. H. Olsen (Eds.), Power in families. New York: Wiley.

Pahl, J. (1989). Money and marriage. New York: St. Martin's Press.

Perucci, C. C., Potter, H. R., \& Rhoads, D. L. (1978). Determinants of male family-role performance. Psychology of Women Quarterly, 3, 53-66.

Pleck, J. H. (1983). Husband's paid work and family roles: Current research issues. In H. Lopata \& J. Pleck (Eds.), Research in the interweave of social roles. Greenwich, CT: JAI.

Pleck, J. H. (1985). Working wives/working husbands. Beverly Hills, CA: Sage.

Rallings, E. M., \& Nye, F. I. (1979). Wife-mother employment, family, and society. In W. R. Burr, R. Hill, F. I. Nye, \& I. Reiss (Eds.), Contemporary theories about the family (Vol. 1). New York: Free Press.

Ross, C. (1987). The division of labor at home. Social Forces, 65, 816-833.

Rubin, L. B. (1976). Worlds of pain: Life in the working-class family. New York: Basic Books.

Safilios-Rothschild, C. (1976). A macro- and micro-examination of family power and love: An exchange model. Journal of Marriage and the Family, 38, 355-362.

Shelton, B. A. (1992). Women, men and time: Gender differences in paid work, housework and leisure. New York: Greenwood.

Shelton, B. A., \& Firestone, J. (1988). Time constraints on men and women: Linking household labor to paid labor. Sociology and Social Research, 72, 102-105.

Shelton, B. A., \& John, D. (1990, August 11-15). Patterns of housework and childcare among cohabiting and married women and men. Paper presented at the annual meeting of the American Sociological Association, Washington, DC.

Spitze, G. (1988). Women's employment and family relations: A review. Joumal of Marriage and the Family, 50, 595-618. 
Starrels, M. E. (1994). Gender differences in parent-child relations. Journal of Family Issues, $15,148-165$.

Szinovacz, M. E. (1984). Changing family roles and interactions. In B. B. Hess \& M. B. Sussman (Eds.), Women and the family: Two decades of change. New York: Haworth.

Walker, K. E., \& Woods, M. E. (1976). Time use: A measure of household production of family goods and services. Washginton, DC: American Home Economics Association.

Warner, R. L. (1986). Alternative strategies for measuring household division of labor: A comparison. Journal of Family Issues, 7, 179-195. 